\title{
A meta-analysis of randomized controlled trials comparing the efficacy and safety of anastrozole versus tamoxifen for breast cancer
}

\author{
Yan Yang ${ }^{1}$, Wei Pan², Xinyu Tang ${ }^{1}$, Shuqing Wu${ }^{3}$ and Xinchen Sun ${ }^{1}$ \\ ${ }^{1}$ Department of Radiation Oncology, The First Affiliated Hospital of Nanjing Medical University, Nanjing, China \\ 2 Department of Radiation Oncology, The Affiliated Jiangning Hospital of Nanjing Medical University, Nanjing, China \\ ${ }^{3}$ Department of Radiation Oncology, The Affiliated Danyang Hospital of Nantong University, Nantong, China \\ Correspondence to: Shuqing Wu, email: wsqdy1 108@163.com \\ Xinchen Sun, email: sunxinchen2012@163.com
}

Keywords: breast cancer, anastrozole, tamoxifen, meta-analysis

Received: February 06, $2017 \quad$ Accepted: March 04, 2017

Published: March 22, 2017

Copyright: Yang et al. This is an open-access article distributed under the terms of the Creative Commons Attribution License 3.0 (CC BY

3.0), which permits unrestricted use, distribution, and reproduction in any medium, provided the original author and source are credited.

\section{ABSTRACT}

Whether anastrozole has superior effects to tamoxifen for breast cancer remains controversial. Therefore, we conducted this meta-analysis of randomized controlled trials (RCTs) to compare the efficacy and safety of anastrozole versus tamoxifen as adjuvant therapy in breast cancer. A systematic literature search of PubMed, Web of Science, Embase, and Cochrane library were performed to evaluate the survival benefits and toxicity profiles of patients with breast cancer who were treated with anastrozole or tamoxifen. The main outcome measures included disease-free survival (DFS), recurrence-free survival (RFS), overall survival (OS), overall response rate (ORR), and adverse events. Hazard ratios (HRs) or risk ratios (RRs) with $\mathbf{9 5 \%}$ confidence intervals (CIs) were pooled using a fixed-effects model or random-effects model. Nine RCTs with a total of 15,300 patients met the inclusion criteria and were included in this meta-analysis. Pooled estimates suggested that, anastrozole was associated with a significantly improvement in DFS (HR=0.72, 95\%CI: 0.55-0.94; $P=0.016)$, and ORR ( $R R=1.21,95 \% C I: 1.05-1.39 ; P=0.009)$ than tamoxifen. But it did not prolong OS $(\mathrm{HR}=0.96,95 \% \mathrm{CI}: 0.77-1.21 ; P=0.751)$. Compared with tamoxifen, anastrozole induced a higher incidence of arthralgia $(R R=1.55,95 \% C I$ : 1.20-1.99; $P=0.001)$ and bone pain ( $R R=1.31,95 \% C I: 1.05-1.62 ; P=0.015)$, as well as a lower incidence of vaginal bleeding ( $R R=0.51,95 \% C I$ : $0.28-0.93 ; P=0.029)$, vaginal discharge ( $R R=0.31,95 \% C I: 0.12-0.82 ; P=0.017$ ), and thromboembolic events ( $R R=0.39$, 95\%CI: 0.28-0.55; $P<0.001$ ). Based on the current evidence, patients with breast cancer would benefit from the anastrozole treatment.

\section{INTRODUCTION}

Breast cancer is the most common cancer in women worldwide, with an estimated 1.6 million new cases every year [1]. The treatment options for breast cancer vary depending on histological grade, tumor characteristics, and extent of disease [2]. For premenopausal women with oestrogen receptor (ER)-positive or progesterone receptor $(\mathrm{PgR})$-positive breast cancer, the treatment strategies include ablative surgery [3], radiotherapy [4, 5], cytotoxic chemotherapy, or adjuvant endocrine [6]. The endocrine treatment includes ER antagonist tamoxifen, and luteinisting hormone releasing hormone (LHRH) agonists such as goserelin [7].

Tamoxifen is a selective ER modulator, and it largely or wholly binds to the receptor protein [8]. Previous studies suggest that, treatment with 5 years of tamoxifen could reduce local, contralateral, and distant recurrence rates, as well as decrease the 15-year breast mortality in $75 \%$ to $80 \%$ of patients who had ER positive breast 
cancer $[9,10]$. In the National Surgical Adjuvant Breast and Bowel Project (NSABP) B-24 trial [6], all patients with ductal carcinoma in situ (DCIS) were randomly allocated to receive tamoxifen or matching placebo. At the median follow up of 6 years, tamoxifen significantly reduced the recurrence rate by $37 \%$ as compared with placebo [6]. Retrospective evaluation of the 732 patients demonstrated that tamoxifen was associated with a $51 \%$ reduction in subsequent breast cancer for women with ER-positive DCIS, but no effect in ER-negative patients [11]. Furthermore, in the UK/ANZ DCIS trial [12], 1578 women with locally excised DCIS received the treatment of tamoxifen with or without radiotherapy. After a median follow up of 12.7 years, the rate of new breast cancer events was significantly reduced by $29 \%$ [12]. Tamoxifen also had effects on the reduction of ipsilateral DCIS recurrence, but not the ipsilteral invasive recurrence [12].

Recently, the third-generation aromatase inhibitors have shown beneficial effects in the management of women with early stage breast cancer. And in 2004, the American Society of Clinical Oncology (ASCO) Technology Assessment recommended that, an aromatase inhibitor should be included to reduce the risk of tumor recurrence when treating the hormone-sensitive earlystage breast cancer [13].

Whether the third-generation aromatase inhibitor, anastrozole, has superior effects to tamoxifen in breast cancer remains controversial. To increase power and precision, we conducted this meta-analysis based on relevant randomized controlled trials (RCTs) to compare the efficacy and safety of anastrozole versus tamoxifen as adjuvant therapy in the treatment of women with breast cancer.

\section{MATERIALS AND METHODS}

\section{Literature search}

We conducted a comprehensive search to identify RCTs that compared anastrozole versus tamoxifen in women with breast cancer. Four Databases, including PubMed, Embase, Web of Science, and Cochrane library, were systematic reviewed from inception to November 25, 2016. Search terms used were listed as the followings: ("breast neoplasms" [MeSH Terms] OR ("breast" [All Fields] AND "neoplasms" [All Fields]) OR "breast neoplasms" [All Fields] OR ("breast" [All Fields] AND "cancer" [All Fields]) OR "breast cancer" [All Fields]) AND ("anastrozole" [Supplementary Concept] OR "anastrozole" [All Fields]) AND ("tamoxifen" [MeSH Terms] OR "tamoxifen" [All Fields]). The search was limited to human subjects and RCTs, and no language restriction was imposed. We also searched the ClinicalTrials.gov registry and manually checked the reference lists of the previous reviews and selected articles to identify other potential articles.

\section{Study inclusion}

Published RCTs that met the following criteria were included: (1) study design: RCT; (2) population: women with breast cancer; (3) intervention: anastrozole; (4) comparison: tamoxifen; (5) outcomes: disease-free survival (DFS), recurrence-free survival (RFS), overall survival (OS), overall response rate (ORR), adverse events. When the same population was appeared in several publications, we only included the one with latest or most comprehensive information.

\section{Data extraction}

Two investigators (Yan Yang and Wei Pan) independently extracted the following information from the included studies: first author's name, year of publication, sample size, patients' demographic characteristics, hormone-receptor status, duration of follow up, hazard ratio (HR) with 95\% confidence intervals (95\%CIs) for DFS, RFS, OS, and incidence of adverse events. Disagreements between the investigators were resolved by discussion and consensus.

\section{Risk of bias assessment and grading quality of evidence}

Two investigators (Yan Yang and Xinyu Tang) independently assessed the risk of bias in included studies, using the method recommended by Cochrane Collaboration [14]. We considered each trial as high, low, or unclear risk of bias according to the following criteria: random sequence generation; allocation concealment; blinding of outcome participants and personnel; blinding of outcome assessment; incomplete outcome data; selective reporting and other bias.

The quality of evidence for the outcome measures was evaluated using the Grading of Recommendations Assessment, Development and Evaluation (GRADE) approach [15]. A summary table was constructed using the GRADE Profiler (version 3.6, GRADE Epro).

\section{Statistical analysis}

We calculated HR with 95\%CIs for time-toevent variables, and risk ratios (RRs) with 95\%CIs for dichotomous outcomes. Before the data were synthesized, we first tested the heterogeneity between the included studies using $I^{2}$ statistic and Cochrane Q chi-square test [16]. The studies were considered to have significant statistical heterogeneity when the value of $I^{2}$ was more 
than $50 \%$, or the value of $\mathrm{P}$ was less than 0.10 [16]. When heterogeneity was found among the included studies, a random-effects model (DerSimonian-Laird method) [17] was used to pool the estimates; otherwise, a fixed-effects model (Mantel-Haenszel method) [18] was applied. When considerable heterogeneity was identified, sensitivity analysis was performed by omitting one study in each turn to explore the influence of a single study on the overall pooled estimate. In some studies, the authors provided the Kaplan-Meier curves rather than $\mathrm{HR}$ and $95 \% \mathrm{CI}$; in these cases, we extracted data from the Kaplan-Meier curves using the method described by Tierney [19]. Publication bias was assessed using Begg's [20] and Egger's [21] test. A P-value of less than 0.05 was considered statistically significant. All analyses were performed using STATA version 12.0 (Stata Corporation, College Station, TX, USA).

\section{RESULTS}

\section{Study identification and selection}

A total of 2,457 potential articles were identified from the database search. Of these, 1,584 studies were excluded for duplicate records, and 857 studies were removed after a review of titles/abstracts. Then the fulltext information of remaining 16 publications were scrutinized for further evaluation, and 7 of them were excluded because six were from three large-scale trials, and one did not provide outcomes of interest (Figure 1).Finally nine RCTs (involving 15,300 patients) [22-30] met the inclusion criteria, and they were included in this meta-analysis.

\section{Study characteristics}

The main characteristics of the included studies were presented in Table 1. These trials were published between 2000 and 2016. The total number of included

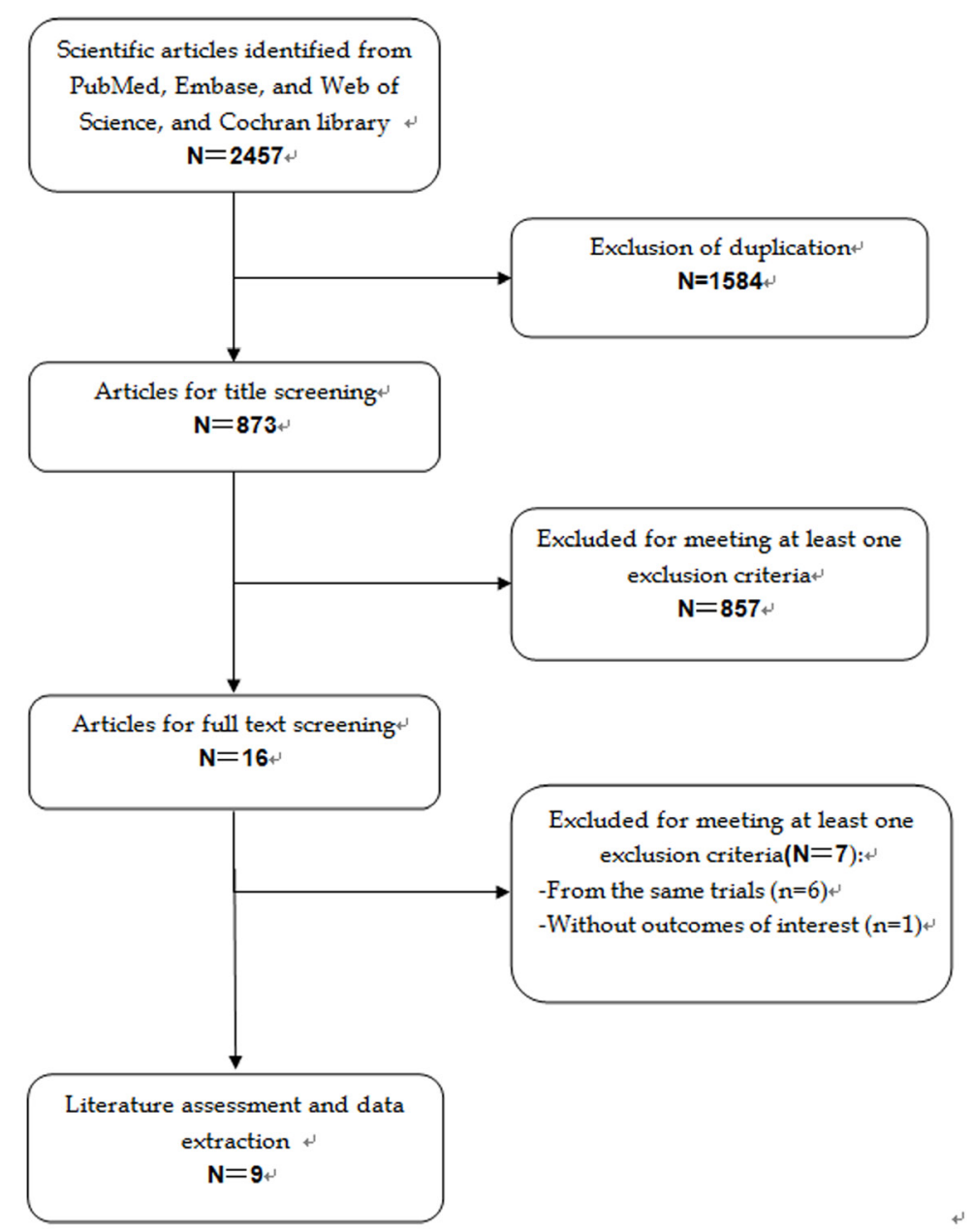

Figure 1: Eligibility of studies for inclusion in meta-analysis. 
Table 1: Baseline characteristics of patients in the trials included in the meta-analysis.

\begin{tabular}{|c|c|c|c|c|c|c|}
\hline Study & Treatment regimen & $\begin{array}{l}\text { No. of } \\
\text { patients }\end{array}$ & Age $($ mean \pm SD, y) & Tumor size (cm) & $\begin{array}{l}\text { ER status } \\
\text { (positive/ } \\
\text { negative/ } \\
\text { unknown) } \\
\end{array}$ & $\begin{array}{l}\text { Median follow- } \\
\text { up(m) }\end{array}$ \\
\hline \multirow[t]{2}{*}{ Margolese RG[22] } & Anastrozole $1 \mathrm{mg}$ & 1552 & $<60 / \geq 60: 731 / 821$ & $\begin{array}{c}<1.0 / \geq 1.0 / \text { unknown: } \\
528 / 389 / 635\end{array}$ & NR & 108(98.4-120) \\
\hline & Tamoxifen $20 \mathrm{mg}$ & 1552 & $<60 / \geq 60: 730 / 822$ & $\begin{array}{c}<1.0 / \geq 1.0 / \text { unknown: } \\
556 / 370 / 626 \\
\end{array}$ & NR & 108(98.4-120) \\
\hline \multirow[t]{2}{*}{ Aihara T[23] } & Anastrozole $1 \mathrm{mg}$ & 345 & $60(45-77)$ & $<3 / \geq 3: 274 / 71$ & $321 / 24 / 0$ & 98.4(2.4-134.4) \\
\hline & Tamoxifen 20mg & 351 & $60(44-82)$ & $<3 / \geq 3: 278 / 73$ & $326 / 25 / 0$ & 98.4(2.4-134.4) \\
\hline \multirow[t]{2}{*}{ Bonneterre J[24] } & Anastrozole $1 \mathrm{mg}$ & 340 & $67(34-91)$ & NR & $146 / 9 / 185$ & 19 \\
\hline & Tamoxifen 20mg & 328 & $66(41-92)$ & NR & $142 / 2 / 184$ & 19 \\
\hline \multirow[t]{2}{*}{ Milla-Santos A[25] } & Anastrozole $1 \mathrm{mg}$ & 121 & $60.2(56-77)$ & NR & NR & 13.3 \\
\hline & Tamoxifen 40mg & 117 & $60.6(55-77)$ & NR & NR & 13.3 \\
\hline \multirow[t]{2}{*}{ Forbes J[26] } & Anastrozole $1 \mathrm{mg}$ & 1449 & $60.4(56.4-64.5)$ & $1.3(0.7-2.2)$ & NR & 86.4(67.2-106.8) \\
\hline & Tamoxifen 20mg & 1489 & $60.3(55.8-64.5)$ & $1.3(0.7-2.2)$ & NR & 86.4(67.2-106.8) \\
\hline \multirow[t]{2}{*}{ Masuda N[27] } & Anastrozole $1 \mathrm{mg}$ & 98 & $<60 / \geq 60: 98 / 0$ & NR & $98 / 0 / 0$ & NR \\
\hline & Tamoxifen 20mg & 99 & $<60 / \geq 60: 99 / 0$ & NR & $99 / 0 / 0$ & NR \\
\hline \multirow[t]{2}{*}{ Nabholtz JM[28] } & Anastrozole $1 \mathrm{mg}$ & 171 & $68(30-88)$ & NR & $145 / 7 / 19$ & 17.7 \\
\hline & Tamoxifen $20 \mathrm{mg}$ & 182 & $67(40-92)$ & NR & $156 / 5 / 21$ & 17.7 \\
\hline \multirow[t]{2}{*}{ Gnant M[29] } & Anastrozole $1 \mathrm{mg}$ & 451 & $45.5(27.6-56.5)$ & NR & $421 / 16 / 14$ & 47.8 \\
\hline & Tamoxifen 20mg & 453 & $45(25.9-56.3)$ & NR & $427 / 15 / 11$ & 47.8 \\
\hline \multirow[t]{2}{*}{ Cuzick J[30] } & Anastrozole $1 \mathrm{mg}$ & 3125 & $64.1 \pm 9.0$ & $\leq 2 />2: 1996 / 1103$ & NR & $120(0-145)$ \\
\hline & Tamoxifen 20mg & 3116 & $64.1 \pm 9.0$ & $\leq 2 />2: 1959 / 1135$ & NR & $120(0-145)$ \\
\hline
\end{tabular}

Abbreviations: NR, not reported; ER, oestrogen receptor

studies was 15,300 patients, ranging from 197 to 6,241 patients per study. The median follow up among these studies ranged from 13.3 to 120 months. Dosage and route of anastrozole in these included studies were consistent, in which anastrozole was orally administered with a dosage of $1 \mathrm{mg}$ per day. However, for tamoxifen, all the studies reported a dosage of $20 \mathrm{mg}$ per day, except the study conducted by Milla-Santos A, et al. [25], which reported a dosage of $40 \mathrm{mg}$ per day.

The ATAC trial was initially reported in 2002 by Baum M, et al. [31], updated in 2003 by Buzdar AU, et al. [32], and finally presented in 2010 by Cuzick J, et al. [30]. Thus, we included the latest version of study presented in 2010, and excluded the initial and updated versions. Similarly, for N-SAS BC03 trial, we included the latest version of study in 2014 conducted by Aihara T, et al. [23], and excluded the initial version in 2010 [33]. However, for TARGET trial, since the original study that reported in 2000 [24] presented the complete information, we included this version of study [24], and excluded the updated version in 2003 by Nabholtz JM, et al. [34].

\section{Risk of bias assessment and quality of evidence}

The details of risk bias are summarized in Figure 2. Overall, three trials were considered as being at low risk of bias [22, 26, 27], and the remaining six as being unclear [23-25, 28-30]. Randomized sequence was adequately generated in eight trials [22-28, 30], and allocation sequence concealment was adequately reported in six studies [22, 23, 25-27, 29]. Blinding of participants and personnel and blinding of outcome assessors were reported in all these included trials.

The GRADE evidence profiles for these outcomes were shown in Table 2. The quality of evidence was high for DFS, RFS, OS, ORR and adverse events.

\section{Disease free survival}

Seven studies reported the data for DFS [22-25, 28$30]$. The pooled estimates demonstrated that anastrozole significantly prolonged DFS compared with tamoxifen $(\mathrm{HR}=0.72,95 \% \mathrm{CI}: 0.55-0.94 ; P=0.016)$ (Figure 3$)$. The test for heterogeneity was significant $\left(P<0.001, I^{2}\right.$ $=92.3 \%$ ). Therefore, we conducted sensitivity analysis to explore the potential heterogeneity. A trial conducted by Milla-Santos A, et al. [25], reported patients with postmenopausal, hormone-dependent, advance breast cancer and they were treated with anastrozole $1 \mathrm{mg}$ or tamoxifen $40 \mathrm{mg}$ per day. When we excluded this trial, the overall estimates did not change substantially (HR $=0.89,95 \% \mathrm{CI}: 0.80-1.00 ; P=0.050)$, but no evidence of heterogeneity was found $\left(P=0.077, I^{2}=47.4 \%\right)$. The Begg and Egger's test showed that there was no potential publication bias among the included studies (Egger's test, $P=0.213$; Begg's test, $P=0.133$ ). 




Figure 2: Risk of bias summary. 
Table 2: GRADE evidence profile.

\begin{tabular}{|c|c|c|c|c|c|c|c|c|c|c|c|c|}
\hline \multicolumn{7}{|c|}{ Quality assessment } & \multicolumn{2}{|c|}{ No of patients } & \multicolumn{2}{|r|}{ Effect } & \multirow{2}{*}{ Quality } & \multirow{2}{*}{ Importance } \\
\hline $\begin{array}{l}\text { No of } \\
\text { studies }\end{array}$ & Design & Risk of bias & Inconsistency & Indirectness & Imprecision & $\begin{array}{c}\text { Other } \\
\text { considerations }\end{array}$ & Anastrozole & Tamoxifen & $\begin{array}{l}\text { Relative } \\
(95 \% \mathrm{CI})\end{array}$ & Absolute & & \\
\hline \multicolumn{13}{|c|}{ Disease free survival (Better indicated by lower values) } \\
\hline 8 & $\begin{array}{l}\text { randomized } \\
\text { trials }\end{array}$ & $\mid \begin{array}{l}\text { no serious } \\
\text { risk of bias }\end{array}$ & serious ${ }^{1}$ & $\mid \begin{array}{ll}\text { no } & \text { serious } \\
\text { indirectness }\end{array}$ & $\begin{array}{l}\text { no serious } \\
\text { imprecision }\end{array}$ & $\begin{array}{l}\text { very strong } \\
\text { association }\end{array}$ & 7483 & 7493 & - & $\begin{array}{c}\text { WMD } 0.72 \text { higher }(0.55 \text { to } 0.94 \\
\text { higher })\end{array}$ & $\begin{array}{c}\text { पिएव } \\
\mathrm{HIGH}\end{array}$ & CRITICAL \\
\hline \multicolumn{13}{|c|}{ Recurrence free survival (Better indicated by lower values) } \\
\hline 7 & $\begin{array}{l}\text { randomized } \\
\text { trials }\end{array}$ & $\mid \begin{array}{l}\text { no serious } \\
\text { risk of bias }\end{array}$ & no $\quad$ serious & no serious & $\begin{array}{l}\text { no serious } \\
\text { imprecision }\end{array}$ & $\begin{array}{l}\text { strong } \\
\text { association }\end{array}$ & 8811 & 8865 & - & $\begin{array}{c}\text { WMD } 0.86 \text { higher }(0.76 \text { to } 0.98 \\
\text { higher })\end{array}$ & $\begin{array}{c}\square \square D \\
\text { HIGH }\end{array}$ & CRITICAL \\
\hline \multicolumn{13}{|c|}{ Over survival (Better indicated by lower values) } \\
\hline 5 & $\begin{array}{l}\text { randomized } \\
\text { trials }\end{array}$ & $\mid \begin{array}{l}\text { no serious } \\
\text { risk of bias }\end{array}$ & no $\quad$ serious & no $\begin{array}{ll}\text { no } & \text { serious } \\
\text { indirectness }\end{array}$ & no $\quad$ serious & none & 8079 & 8122 & - & $\begin{array}{c}\text { WMD } 0.96 \text { higher }(0.77 \text { to } 1.21 \\
\text { higher })\end{array}$ & $\begin{array}{c}\text { पिएर } \\
\text { HIGH }\end{array}$ & IMPORTANT \\
\hline \multicolumn{13}{|c|}{ Overall response rate } \\
\hline 5 & $\begin{array}{l}\text { randomized } \\
\text { trials }\end{array}$ & no serious & no $\quad$ serious & so $\begin{array}{ll}\text { no } & \text { serious } \\
\text { indirectness }\end{array}$ & $\begin{array}{l}\text { no } \quad \text { serious } \\
\text { imprecision }\end{array}$ & none & $\begin{array}{l}267 / 730 \\
(36.6 \%)\end{array}$ & $\begin{array}{l}219 / 726 \\
(30.2 \%)\end{array}$ & $\begin{array}{c}\text { RR } 1.21(1.05 \\
\text { to } 1.39)\end{array}$ & $\begin{array}{c}43 \text { more per } 1000 \text { (from } 3 \text { more } \\
\text { to } 87 \text { more) }\end{array}$ & $\begin{array}{l}\text { पि口प } \\
\text { HIGH }\end{array}$ & IMPORTANT \\
\hline \multicolumn{13}{|c|}{ Adverse events } \\
\hline 10 & $\begin{array}{l}\text { randomized } \\
\text { trials }\end{array}$ & $\begin{array}{l}\text { no serious } \\
\text { risk of bias }\end{array}$ & $\mid \begin{array}{ll}\text { no } & \text { serious } \\
\text { inconsistency }\end{array}$ & no $\begin{array}{ll}\text { no } & \text { serious } \\
\text { indirectness }\end{array}$ & $\begin{array}{l}\text { no serious } \\
\text { imprecision }\end{array}$ & none & $\begin{array}{l}669 / 4660 \\
(14.7 \%)\end{array}$ & $\begin{array}{c}821 / 4651 \\
(17.7 \%)\end{array}$ & $\begin{array}{c}\text { RR } 0.77(0.47 \\
\text { to } 1.25)\end{array}$ & $\begin{array}{l}41 \text { fewer per } 1000 \text { (from } 94 \\
\text { fewer to } 44 \text { more) }\end{array}$ & $\begin{array}{c}\mathrm{QDO} \\
\mathrm{HIGH}\end{array}$ & IMPORTANT \\
\hline
\end{tabular}

${ }^{1}$ Substantial heterogeneity $\left(I^{2}=92.3 \%\right)$ was found ${ }^{2} \mathrm{~A}$ total of 14,976 patients were enrolled.

\section{Recurrence free survival}

Seven studies reported the data for RFS [22-24, 26, 28-30]. The aggregated results of these studies indicated that, anastrozole was associated with a significantly improved RFS than tamoxifen (HR $=0.86,95 \% \mathrm{CI}$ : 0.76 $0.98 ; P=0.024)$ (Figure 4). There was a little statistical heterogeneity among the included studies $\left(P=0.043, I^{2}=\right.$ $53.9 \%)$. The Begg and Egger's test revealed no existence of publication bias among the included studies (Egger's test, $P=0.806$; Begg's test, $P=0.881$ ).

\section{Over survival}

Eight of the nine included studies reported OS outcome, but only five provided available data for analysis $[22,25,26,29,30]$. The pooled results showed that anastrozole did not significantly improve OS as compared with tamoxifen (HR $=0.96,95 \% \mathrm{CI}$ : $0.77-1.21 ; P=0.751)$ (Figure 5). The test for heterogeneity was significant $\left(P=0.020, I^{2}=65.8 \%\right)$. Therefore, we conducted the sensitivity analysis. When we removed trial conducted by Milla-Santos A, et al. [25], the pooled results changed slightly $(\mathrm{HR}=1.00,95 \% \mathrm{CI}$ : $0.91-1.09 ; P=0.924)$, but no evidence of heterogeneity was observed among the remaining studies $\left(P=0.239, I^{2}=28.9 \%\right)$.

\section{Overall response rate}

Four studies reported the data for ORR [24, 25, $27,28]$. The pooled results suggested that patients with breast cancer who were treated with anastrozole had a higher ORR than those treated with tamoxifen $(\mathrm{RR}=1.21$, 95\% CI: $1.05-1.39 ; P=0.009$ ) (Figure 6). The test for heterogeneity was not significant $\left(P=0.400, I^{2}=0.0 \%\right)$.

\section{Adverse events}

All the studies reported the data for adverse events [22-30]. The incidences of adverse events in the anastrozole and tamoxifen groups were $14.4 \%$ and $17.7 \%$, respectively. Pooled estimates showed that, anastrozole had a comparable incidence of adverse events as tamoxifen ( $\mathrm{RR}=0.77,95 \% \mathrm{CI}: 0.47-1.25 ; P=0.303$ ). The most common adverse events are listed in Table 3. The pooled results demonstrated that, compared with tamoxifen, anastrozole was associated with a significantly higher incidence of arthralgia ( $\mathrm{RR}=1.55,95 \% \mathrm{CI}: 1.20$ $1.99 ; P=0.001)$, bone pain $(\mathrm{RR}=1.31,95 \% \mathrm{CI}: 1.05$ $1.62 ; P=0.015)$, but a lower incidence of vaginal bleeding $(\mathrm{RR}=0.51,95 \% \mathrm{CI}: 0.28-0.93 ; P=0.029)$, vaginal discharge $(\mathrm{RR}=0.31,95 \% \mathrm{CI}: 0.12-0.82 ; P=0.017)$, and thromboembolic events $(\mathrm{RR}=0.39,95 \% \mathrm{CI}$ : $0.28-0.55 ; P$ $<0.001)$.

\section{DISCUSSION}

This study is a meta-analysis with the objective of comparing the efficacy and safety of anastrozole versus tamoxifen as adjuvant treatment for breast cancer. Our study suggested that, anastrozole was associated with a significantly improvement in DFS, RFS and ORR than tamoxifen, but was not in OS. Moreover, anastrozole induced a higher incidence of arthralgia and bone pain, as well as a lower incidence of vaginal bleeding, vaginal 
discharge, and thromboembolic events than tamoxifen. These results suggested that women with breast cancer could benefit from treatment of anastrozole.

There has been one published meta-analysis that assessed the effect of switching to anastrozole after 2-3 years of tamoxifen treatment, compared with continuing on tamoxifen for 5 years [35]. In that study, the authors included three clinical trials: the ABCSG- 8 trial, ArimidexNolvadex (ARNO 95), and the Italian Tamoxifen Anastrozole (ITA) [35]. All the postmenopausal women enrolled had histologically confirmed, hormone-sensitivity early stage breast cancer, and were randomized to receive $1 \mathrm{mg} /$ day anastrozole after 2-3 years of tamoxifen treatment or to continued 20 or $30 \mathrm{mg}$ /day tamoxifen [35]. Their results suggested that, compared with continuing on tamoxifen, switching to anastrozole was associated with a significant improvements in DFS (HR $=0.59$, 95\%CI: $0.48-0.74 ; P<0.001$ ), event-free survival (HR $=0.55,95 \% \mathrm{CI}: 0.42-0.71 ; P<0.001)$, and distant RFS $(\mathrm{HR}=0.61,95 \% \mathrm{CI}: 0.45-0.83 ; P=0.002)$ [35]. These results were comparable to data from our meta-analysis. However, with regard to the OS, we observed a converse result with this previously published meta-analysis. In the present study, the anastrozole treatment had a similar OS with tamoxifen. While, in the previous meta-analysis, the treatment of switching to anastrozole resulted in an improved OS than continuing on tamoxifen $(\mathrm{HR}=0.71$,
95\% CI: 0.52-0.98; $P=0.004)$ [35].

In this meta-analysis, anastrozole significantly reduced the risk of disease progression by $28 \%$ (HR = 0.72 , 95\%CI: $0.55-0.94 ; P=0.016)$. This finding was consistent with the result of the ATAC trial [30], which also reported a beneficial effect of anastrozole over tamoxifen. ATAC trial was a randomized, multicenter trial that compared the efficacy and safety of anastrozole $(1 \mathrm{mg})$ with tamoxifen $(20 \mathrm{mg})$, both given orally every day for 5 years, as adjuvant treatment for women with earlystage breast cancer [30]. After a median follow up of 120 months (range 0-145), 30.5\% (953/3125) and 32.8\% (1022/3116) of patients in the anastrozole and tamoxifen groups developed disease progression, respectively. The corresponding HR for DFS was 0.91(95\%CI: 0.83-0.99; $P=0.04$ ) [30]. Moreover, this survival benefit was also observed in patients with hormone-receptor positive disease, which reported a $14 \%$ less of risk for developing disease progression $(\mathrm{HR}=0.86,95 \% \mathrm{CI}$ : 0.78-0.95; $P=$ 0.03) [30].

However, the improvement of DFS associated with anastrozole was not observed in a phase 3 National Surgical Adjuvant Breast and Bowel Project (NSABP) B-35 trial [22]. In that trial, postmenopausal women with hormone-positive ductal carcinoma in situ were randomly assigned to receive either oral anastrozole $1 \mathrm{mg}$ per day or tamoxifen $20 \mathrm{mg}$ per day [22]. At the end of 10-years'

\begin{tabular}{|c|c|c|}
\hline Study & & $\%$ \\
\hline ID & $\mathrm{HR}(95 \% \mathrm{Cl})$ & Weight \\
\hline Margolese RG (2016) & $0.89(0.75,1.07)$ & 15.47 \\
\hline Aihara T (2014) & $0.90(0.65,1.24)$ & 13.40 \\
\hline Bonneterre J (2000) & $0.99(0.86,1.16)$ & 15.77 \\
\hline Milla-Santos A (2003) $\longleftrightarrow$ & $0.13(0.08,0.20)$ & 11.23 \\
\hline Nabholtz JM (2000) & $0.64(0.52,0.84)$ & 14.66 \\
\hline Gnant M (2009) & $1.10(0.78,1.53)$ & 13.18 \\
\hline Cuzick J (2010) & $0.91(0.83,0.99)$ & 16.29 \\
\hline Overall (I-squared $=92.3 \%, p=0.000)$ & $0.72(0.55,0.94)$ & 100.00 \\
\hline NOTE: Weights are from random effects analysis & & \\
\hline .08 & & \\
\hline
\end{tabular}

Figure 3: Forest plot showing the effect of anastrozole versus tamoxifen on disease free survival. 
Table 3: Summary of the risk ration (RR) of adverse events

\begin{tabular}{|l|c|c|c|}
\hline \multicolumn{1}{|c|}{ Adverse events } & Risk ratio (RR) & $\mathbf{9 5 \% ~ C I ~}$ & P value \\
\hline Arthralgia & 1.55 & $1.20-1.99$ & 0.001 \\
\hline Bone pain & 1.31 & $1.05-1.62$ & 0.015 \\
\hline Vaginal bleeding & 0.51 & $0.28-0.93$ & 0.017 \\
\hline Vaginal discharge & 0.31 & $0.12-0.82$ & $<0.001$ \\
\hline Thromboembolism & 0.39 & $0.28-0.55$ & 0.987 \\
\hline Nausea & 1.00 & $0.82-1.23$ & 0.551 \\
\hline Hot flush & 0.95 & $0.82-1.11$ & 0.756 \\
\hline Hypertension & 0.92 & $0.53-1.59$ & 0.072 \\
\hline Bone fracture & 1.16 & $0.99-1.35$ & 0.059 \\
\hline Constipation & 0.62 & $0.38-1.02$ & 0.245 \\
\hline Diarrhea & 1.35 & $0.81-2.24$ & \\
\hline
\end{tabular}

follow up, the DFS rate in these two groups were $82.7 \%$ and $77.9 \%$, respectively [22]. Although there were strong trends toward improved DFS in the anastrozole group, this difference was not statistically significant $(\mathrm{HR}=0.89$, 95\%CI: 0.75-1.07; $P=0.21$ ). Furthermore, when the DFS outcome was analyzed based on age, significant effect was observed in women aged younger than 60 years $(\mathrm{HR}=$ 0.69, 95\%CI: $0.51-0.93 ; P=0.02$ ) [22]. Thus, the authors concluded that young women would achieve a better DFS than older women, although there was no obvious biological explanation for this difference [22]. Owning to the limited data, we did not perform subgroup analysis

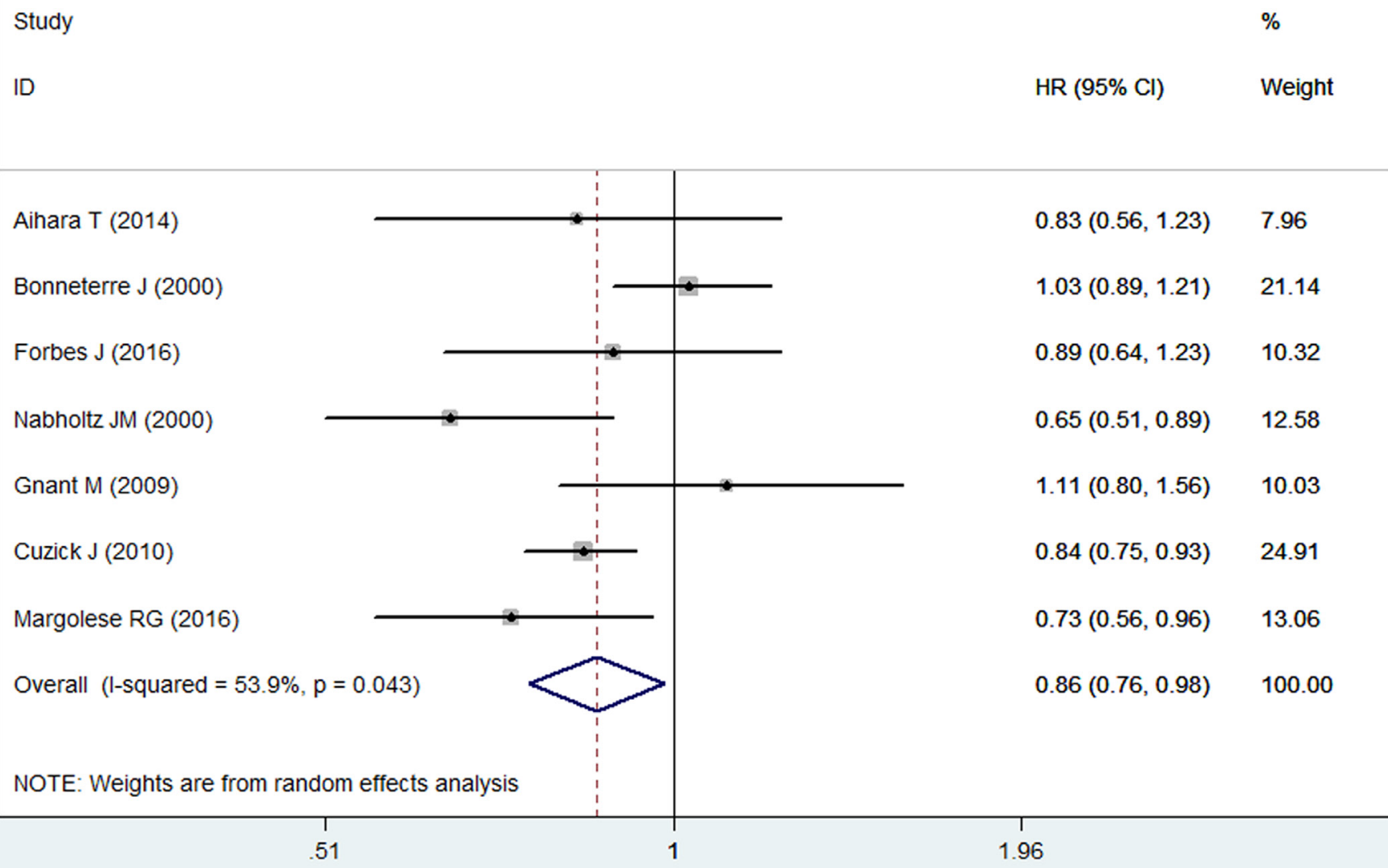

Figure 4: Forest plot showing the effect of anastrozole versus tamoxifen on recurrence free survival. 
to explore whether the effect of anastrozole was only restricted to women who were younger than 60 years old.

Regarding the RFS, our study showed that patients who were treated with anastrozole had an improved RFS compared with tamoxifen ( $\mathrm{HR}=0.86,95 \% \mathrm{CI}$ : 0.76-0.98; $P=0.024)$. This result was in line with the data from the ATAC trial [30]. In that study, the RFS rate in the anastrozole and tamoxifen group was $19.6 \%$ and $23.0 \%$, respectively $(\mathrm{HR}=0.84$, 95CI: 0.75-0.93). However, this survival benefit was only observed in subpopulation patients who had hormone receptor positive disease [30]. Among these patients, the recurrence rates in these two groups were $17.1 \%$ and $21.5 \%$, respectively, and the HR for RFS was 0.79 (95\%CIs: 0.70-0.89).

Contrast to the ATAC trial, IBIS-II DCIS trial did not find a statistically significant difference in RFS [26]. IBISII DCIS trial was a double-blind, multicenter, randomized placebo-control trial, which enrolled postmenopausal women with hormone-receptor-positive DCIS [26]. In that study, $67(4.62 \%)$ patients in the anastrozole group and $77(5.17 \%)$ patients in the tamoxifen group developed breast cancer recurrences, respectively [26]. The corresponding value for HR with $95 \%$ CIs was 0.89 (0.64-1.23) [26]. Furthermore, when the authors used the univariate analyses to calculate HR values, the comparable effect was still present between the two groups [26]. This might be explained by the history of DCIS in these patients. According to the previous studies, DCIS had been recognized as a precursor of invasive cancer, and patients with DCIS was more likely to develop invasive breast cancer $[36,37]$. Another interesting finding in the IBIS-II DCIS trial was that, the improved RFS was only observed in ER-positive patients, but not in ER-negative patients. Among the 86 ER-positive recurrences, 30 (2\%) occurred in the anastrozole group compared with 56(4\%) in the tamoxifen group ( $\mathrm{HR}=0.55,95 \% \mathrm{CI}$ : $0.35-0.86$ ), which indicated a benefit in favor of anastrozole [26]. Whereas, for the 30 ER-negative recurrences, 17 (1\%) were in the anastrozole group compared with $13(<1 \%)$ in tamoxifen group $(\mathrm{HR}=1.34,95 \mathrm{CI}$ : 0.65-2.75), which suggested a similar effect between the two treatments [26]. Previous studies have suggested that the hormone receptor status was an important factor in predicting the treatment effects of endocrine therapy: patients with hormone receptor positive tumors would achieve the greatest effect, whereas those with hormone receptor negative tumors were questionable $[38,39]$. This could explain why the beneficial effect of anastrozole was only observed in ERpositive patients but not in ER-negative patients.

Among the included studies, the improvement of OS was only observed in a phase III trial [25], in which anastrozole was used as first-line therapy. In this trial, 121 and 117 patients were randomized to receive anastrozole or tamoxifen, respectively. At the time of data cutoff, $60 \%$ of patients died in the anastrozole group as compared with $89 \%$ in the tamoxifen group [25]. The median OS

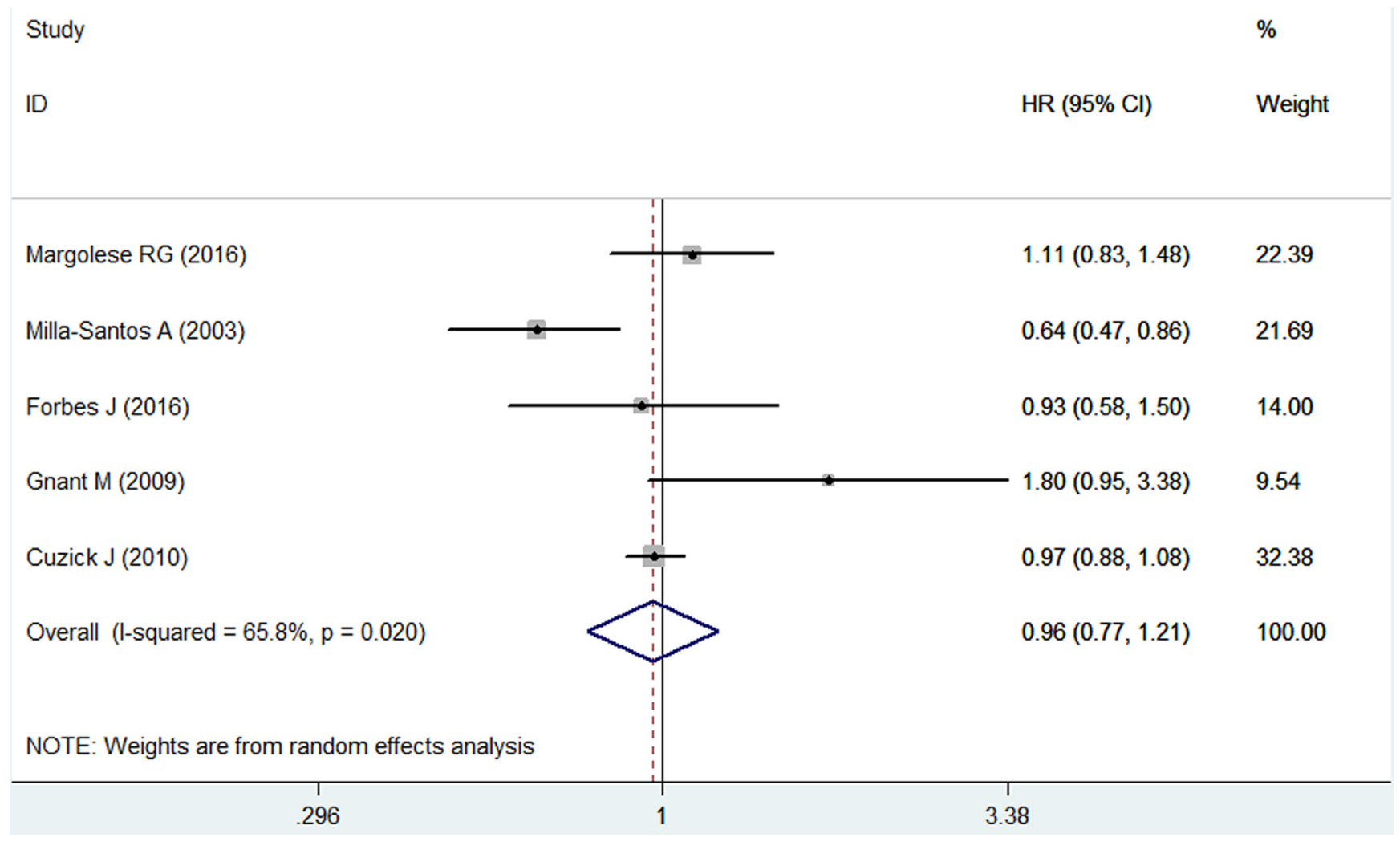

Figure 5: Forest plot showing the effect of anastrozole versus tamoxifen on overall survival. 
times for the two groups were 17.4 and 16.0 months, respectively ( $\mathrm{HR}=0.64,95 \mathrm{CI}: 0.47-0.86 ; P=0.003)$ [25], indicating that anastrozole significantly reduced the risk of death by $36 \%$ as compared with tamoxifen. However, in the Austrian Breast and Colorectal Cancer Study Group trial 12 (ABCSG-12) [29], anastrozole resulted in an opposite result. In that study, anastrozole had similar effects with tamoxifen in OS, and the HR for OS was 1.80 (95\%CI: $0.95-3.38 ; P=0.007$ ) [29]. Although there was a strong trend for improved OS in tamoxifen group than anastrozole group, the difference between them was not significant [29]. The precise reason for the prolonged OS in favor of tamoxifen is not clear, however, it was speculated that the absence of palliative treatment with aromatase inhibitors in the anastrozole group could affect the OS $[29,40]$.

Additionally, the BMI may also have potential impact on the OS. In a retrospective analysis of ABCSG-12 trial [41], the authors found a greater OS in favor of tamoxifen plus gosereline over anastrozole plus goserelin. However, this beneficial effect was only observed in the subset of patients with BMI $>25 \mathrm{~kg} / \mathrm{m}^{2}$, but not in those with BMI $<25 \mathrm{~kg} / \mathrm{m}^{2}$ [41]. Similarly, in the retrospective analysis from the ATAC trial [42], obese women (BMI $\left.>30 \mathrm{~kg} / \mathrm{m}^{2}\right)$ treated with anastrozole had a poorer overall prognosis than those with BMI lower than $23 \mathrm{~kg} / \mathrm{m}^{2}$ [42]. It seemed that patients with BMI $>25 \mathrm{~kg} /$ $\mathrm{m}^{2}$ would achieve a better OS when they were treated with tamoxifen, while those with BMI $<25 \mathrm{~kg} / \mathrm{m}^{2}$ might obtain a greater OS when they were treated with anastrozole. This also could explain the better efficacy for tamoxifen than for anastrozole in the ABCSG-12 trial [41], since 33.0\% of patients in that study had a BMI higher than $25 \mathrm{~kg} / \mathrm{m}^{2}$.

In this meta-analysis, we found that the overall incidence of adverse events was similar between the anastrozole and tamoxifen groups. Patients treated with anastrozole had a significantly fewer vaginal bleeding, vaginal discharge, and thromboembolic events than did those treated with tamoxifen. Most of these drug-related adverse events were mainly mild to moderate in severity. In the overall analysis, anastrozole seems to have a preferable safety profile to tamoxifen for adverse events.

This meta-analysis has several potential limitations that should be considered. First, there was substantial heterogeneity in DFS outcomes among the included studies. However, it should not be surprising when considering the differences in region, ethnicity, BMI, hormone receptor status, tumor grade, the dosage of tamoxifen, and duration of follow up. These factors may result in an overestimation or underestimation of the true DFS. Second, due to the sparse reporting among these trials, we did not compare the effects of anastrozole over tamoxifen in subset of patients with different ER status, hormone receptor status, and BMI. Third, because all of these trials were partly funded by the pharmaceutical industry, we could not exclude the possibility that their

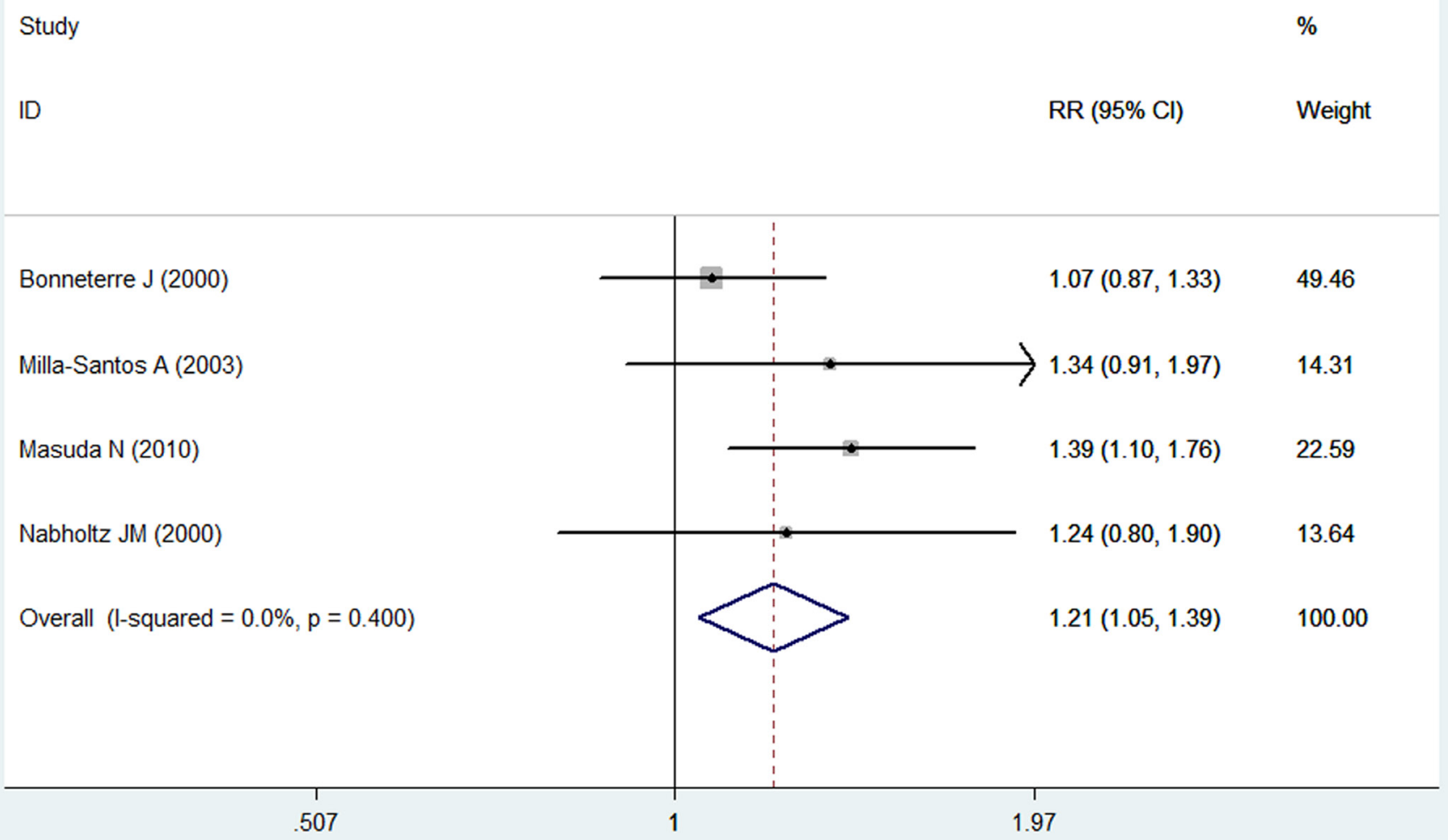

Figure 6: Forest plot showing the effect of anastrozole versus tamoxifen on overall response rate. 
results were affected by the inherent conflict of interest and possible bias. Therefore, cautions should be taken when interpreting our results.

In conclusion, our meta-analysis indicated that, anastrozole was associated with an improvement in DFS, RFS and ORR in the treatment of patients with breast cancer, but not in OS. Moreover, anastrozole also produced a comparable incidence of adverse events with tamoxifen. However, given the potential limitations in this study, additional large-scale and well-designed RCTs are needed to substantiate our findings, and investigate the effects of anastrozole in subpopulation patients with different ER status, hormone receptor status, and BMI.

\section{Authors' contributions}

Y Yang and W Pan mainly participated in literature search, study design, writing and critical revision. XY Tang, SQ Wu, and XC Sun mainly participated in data collection, data analysis and data interpretation. All authors read and approved the final manuscript.

\section{CONFLICTS OF INTEREST}

All the authors declare that they have no conflict of interest.

\section{Ethics approval and consent to participate}

Not applicable.

\section{REFERENCES}

1. Jemal A, Bray F, Center MM, Ferlay J, Ward E, Forman D. Global cancer statistics. CA Cancer J Clin. 2011; 61: 69-90. doi: 10.3322/caac.20107.

2. Cuzick J, Sestak I, Forbes JF, Dowsett M, Knox J, Cawthorn S, Saunders C, Roche N, Mansel RE, von Minckwitz G, Bonanni B, Palva T, Howell A. Anastrozole for prevention of breast cancer in high-risk postmenopausal women (IBISII): an international, double-blind, randomised placebocontrolled trial. Lancet. 2014; 383: 1041-8. doi: 10.1016/ s0140-6736(13)62292-8.

3. Worni M, Akushevich I, Greenup R, Sarma D, Ryser MD, Myers ER, Hwang ES. Trends in Treatment Patterns and Outcomes for Ductal Carcinoma In situ. J Natl Cancer Inst. 2015; 107: djv263. doi: 10.1093/jnci/djv263.

4. Goodwin A, Parker S, Ghersi D, Wilcken N. Post-operative radiotherapy for ductal carcinoma in situ of the breast. Cochrane Database Syst Rev. 2013: Cd000563. doi: 10.1002/14651858.CD000563.pub7.

5. Dodwell D, Clements K, Lawrence G, Kearins O, Thomson CS, Dewar J, Bishop H. Radiotherapy following breastconserving surgery for screen-detected ductal carcinoma in situ: indications and utilisation in the UK. Interim findings from the Sloane Project. Br J Cancer. 2007; 97: 725-9. doi: 10.1038/sj.bjc.6603945.

6. Fisher B, Dignam J, Wolmark N, Wickerham DL, Fisher ER, Mamounas E, Smith R, Begovic M, Dimitrov NV, Margolese RG, Kardinal CG, Kavanah MT, Fehrenbacher L, et al. Tamoxifen in treatment of intraductal breast cancer: National Surgical Adjuvant Breast and Bowel Project B-24 randomised controlled trial. Lancet. 1999; 353: 1993-2000. doi: 10.1016/s0140-6736(99)05036-9.

7. Jonat W, Kaufmann M, Sauerbrei W, Blamey R, Cuzick J, Namer M, Fogelman I, de Haes JC, de Matteis A, Stewart A, Eiermann W, Szakolczai I, Palmer M, et al. Goserelin versus cyclophosphamide, methotrexate, and fluorouracil as adjuvant therapy in premenopausal patients with nodepositive breast cancer: The Zoladex Early Breast Cancer Research Association Study. J Clin Oncol. 2002; 20: 462835 .

8. Jordan VC. The science of selective estrogen receptor modulators: concept to clinical practice. Clin Cancer Res. 2006; 12: 5010-3. doi: 10.1158/1078-0432.ccr-06-1136.

9. Early Breast Cancer Trialists' Collaborative Group (EBCTCG). Effects of chemotherapy and hormonal therapy for early breast cancer on recurrence and 15-year survival: an overview of the randomised trials. Lancet. 2005; 365: 1687-717. doi: 10.1016/s0140-6736(05)66544-0.

10. Early Breast Cancer Trialists' Collaborative Group. Effects of adjuvant tamoxifen and of cytotoxic therapy on mortality in early breast cancer. An overview of 61 randomized trials among 28,896 women. N Engl J Med. 1988; 319: 1681-92. doi: 10.1056/nejm198812293192601.

11. Allred DC, Anderson SJ, Paik S, Wickerham DL, Nagtegaal ID, Swain SM, Mamounas EP, Julian TB, Geyer CE Jr, Costantino JP, Land SR, Wolmark N. Adjuvant tamoxifen reduces subsequent breast cancer in women with estrogen receptor-positive ductal carcinoma in situ: a study based on NSABP protocol B-24. J Clin Oncol. 2012; 30: 1268-73. doi: $10.1200 /$ jco.2010.34.0141.

12. Cuzick J, Sestak I, Pinder SE, Ellis IO, Forsyth S, Bundred NJ, Forbes JF, Bishop H, Fentiman IS, George WD. Effect of tamoxifen and radiotherapy in women with locally excised ductal carcinoma in situ: long-term results from the UK/ANZ DCIS trial. Lancet Oncol. 2011; 12: 21-9. doi: 10.1016/s1470-2045(10)70266-7.

13. Winer EP, Hudis C, Burstein HJ, Wolff AC, Pritchard KI, Ingle JN, Chlebowski RT, Gelber R, Edge SB, Gralow J, Cobleigh MA, Mamounas EP, Goldstein LJ, et al. American Society of Clinical Oncology technology assessment on the use of aromatase inhibitors as adjuvant therapy for postmenopausal women with hormone receptor-positive breast cancer: status report 2004. J Clin Oncol. 2005; 23: 619-29. doi: 10.1200/jco.2005.09.121.

14. Higgins JP, Altman DG, Gotzsche PC, Juni P, Moher D, Oxman AD, Savovic J, Schulz KF, Weeks L, Sterne JA. The Cochrane Collaboration's tool for assessing risk of bias 
in randomised trials. Bmj. 2011; 343: d5928. doi: 10.1136/ bmj.d5928.

15. Guyatt GH, Oxman AD, Vist GE, Kunz R, Falck-Ytter Y, Alonso-Coello P, Schunemann HJ. GRADE: an emerging consensus on rating quality of evidence and strength of recommendations. Bmj. 2008; 336: 924-6. doi: 10.1136/ bmj.39489.470347.AD.

16. Higgins JP, Thompson SG, Deeks JJ, Altman DG. Measuring inconsistency in meta-analyses. Bmj. 2003; 327: 557-60. doi: 10.1136/bmj.327.7414.557.

17. DerSimonian R, Laird N. Meta-analysis in clinical trials. Control Clin Trials. 1986; 7: 177-88.

18. Mantel N, Haenszel W. Statistical aspects of the analysis of data from retrospective studies of disease. J Natl Cancer Inst. 1959; 22: 719-48.

19. Tierney JF, Stewart LA, Ghersi D, Burdett S, Sydes MR. Practical methods for incorporating summary time-toevent data into meta-analysis. Trials. 2007; 8: 16. doi: 10.1186/1745-6215-8-16.

20. Begg CB, Mazumdar M. Operating characteristics of a rank correlation test for publication bias. Biometrics. 1994; 50: 1088-101.

21. Egger M, Davey Smith G, Schneider M, Minder C. Bias in meta-analysis detected by a simple, graphical test. Bmj. 1997; 315: 629-34.

22. Margolese RG, Cecchini RS, Julian TB, Ganz PA, Costantino JP, Vallow LA, Albain KS, Whitworth PW, Cianfrocca ME, Brufsky AM, Gross HM, Soori GS, Hopkins JO, et al. Anastrozole versus tamoxifen in postmenopausal women with ductal carcinoma in situ undergoing lumpectomy plus radiotherapy (NSABP B-35): a randomised, double-blind, phase 3 clinical trial. Lancet. 2016; 387: 849-56. doi: 10.1016/s0140-6736(15)01168-x.

23. Aihara T, Yokota I, Hozumi Y, Aogi K, Iwata H, Tamura M, Fukuuchi A, Makino H, Kim R, Andoh M, Tsugawa K, Ohno S, Yamaguchi T, et al. Anastrozole versus tamoxifen as adjuvant therapy for Japanese postmenopausal patients with hormone-responsive breast cancer: efficacy results of long-term follow-up data from the N-SAS BC 03 trial. Breast Cancer Res Treat. 2014; 148: 337-43. doi: 10.1007/ s10549-014-3155-8.

24. Bonneterre J, Thurlimann B, Robertson JF, Krzakowski M, Mauriac L, Koralewski P, Vergote I, Webster A, Steinberg $\mathrm{M}$, von Euler M. Anastrozole versus tamoxifen as first-line therapy for advanced breast cancer in 668 postmenopausal women: results of the Tamoxifen or Arimidex Randomized Group Efficacy and Tolerability study. J Clin Oncol. 2000; 18: 3748-57.

25. Milla-Santos A, Milla L, Portella J, Rallo L, Pons M, Rodes E, Casanovas J, Puig-Gali M. Anastrozole versus tamoxifen as first-line therapy in postmenopausal patients with hormone-dependent advanced breast cancer: a prospective, randomized, phase III study. Am J Clin Oncol. 2003; 26: 317-22. doi: 10.1097/01.coc.0000047126.10522. f9.

26. Forbes JF, Sestak I, Howell A, Bonanni B, Bundred N, Levy C, von Minckwitz G, Eiermann W, Neven P, Stierer M, Holcombe C, Coleman RE, Jones L, et al. Anastrozole versus tamoxifen for the prevention of locoregional and contralateral breast cancer in postmenopausal women with locally excised ductal carcinoma in situ (IBIS-II DCIS): a double-blind, randomised controlled trial. Lancet. 2016; 387: 866-73. doi: 10.1016/s0140-6736(15)01129-0.

27. Masuda N, Sagara Y, Kinoshita T, Iwata H, Nakamura S, Yanagita Y, Nishimura R, Iwase H, Kamigaki S, Takei H, Noguchi S. Neoadjuvant anastrozole versus tamoxifen in patients receiving goserelin for premenopausal breast cancer (STAGE): a double-blind, randomised phase 3 trial. Lancet Oncol. 2012; 13: 345-52. doi: 10.1016/s14702045(11)70373-4

28. Nabholtz JM, Buzdar A, Pollak M, Harwin W, Burton G, Mangalik A, Steinberg M, Webster A, von Euler M. Anastrozole is superior to tamoxifen as first-line therapy for advanced breast cancer in postmenopausal women: results of a North American multicenter randomized trial. Arimidex Study Group. J Clin Oncol. 2000; 18: 3758-67.

29. Gnant M, Mlineritsch B, Schippinger W, LuschinEbengreuth G, Postlberger S, Menzel C, Jakesz R, Seifert M, Hubalek M, Bjelic-Radisic V, Samonigg H, Tausch C, Eidtmann H, et al. Endocrine therapy plus zoledronic acid in premenopausal breast cancer. N Engl J Med. 2009; 360: 679-91. doi: 10.1056/NEJMoa0806285.

30. Cuzick J, Sestak I, Baum M, Buzdar A, Howell A, Dowsett M, Forbes JF. Effect of anastrozole and tamoxifen as adjuvant treatment for early-stage breast cancer: 10-year analysis of the ATAC trial. Lancet Oncol. 2010; 11: 113541. doi: 10.1016/s1470-2045(10)70257-6.

31. Baum M, Budzar AU, Cuzick J, Forbes J, Houghton JH, Klijn JG, Sahmoud T. Anastrozole alone or in combination with tamoxifen versus tamoxifen alone for adjuvant treatment of postmenopausal women with early breast cancer: first results of the ATAC randomised trial. Lancet. 2002; 359: 2131-9.

32. Buzdar AU. 'Arimidex' (anastrozole) versus tamoxifen as adjuvant therapy in postmenopausal women with early breast cancer--efficacy overview. J Steroid Biochem Mol Biol. 2003; 86: 399-403.

33. Aihara T, Takatsuka Y, Ohsumi S, Aogi K, Hozumi Y, Imoto S, Mukai $\mathrm{H}$, Iwata $\mathrm{H}$, Watanabe $\mathrm{T}$, Shimizu $\mathrm{C}$, Nakagami K, Tamura M, Ito T, et al. Phase III randomized adjuvant study of tamoxifen alone versus sequential tamoxifen and anastrozole in Japanese postmenopausal women with hormone-responsive breast cancer: N-SAS BC03 study. Breast Cancer Res Treat. 2010; 121: 379-87. doi: 10.1007/s10549-010-0888-x.

34. Nabholtz JM. Advanced breast cancer updates on anastrozole versus tamoxifen. J Steroid Biochem Mol Biol. 2003; 86: 321-5.

35. Jonat W, Gnant M, Boccardo F, Kaufmann M, Rubagotti A, 
Zuna I, Greenwood M, Jakesz R. Effectiveness of switching from adjuvant tamoxifen to anastrozole in postmenopausal women with hormone-sensitive early-stage breast cancer: a meta-analysis. Lancet Oncol. 2006; 7: 991-6. doi: 10.1016/ s1470-2045(06)70948-2.

36. Page DL, Dupont WD, Rogers LW, Jensen RA, Schuyler PA. Continued local recurrence of carcinoma 15-25 years after a diagnosis of low grade ductal carcinoma in situ of the breast treated only by biopsy. Cancer. 1995; 76: 1197 200.

37. Eusebi V, Feudale E, Foschini MP, Micheli A, Conti A, Riva C, Di Palma S, Rilke F. Long-term follow-up of in situ carcinoma of the breast. Semin Diagn Pathol. 1994; 11: 223-35.

38. Early Breast Cancer Trialists' Collaborative Group. Tamoxifen for early breast cancer: an overview of the randomised trials. Lancet. 1998; 351: 1451-67.

39. Jaiyesimi IA, Buzdar AU, Decker DA, Hortobagyi GN. Use of tamoxifen for breast cancer: twenty-eight years later. J Clin Oncol. 1995; 13: 513-29.
40. Smith IE, Dowsett M, Ebbs SR, Dixon JM, Skene A, Blohmer JU, Ashley SE, Francis S, Boeddinghaus I, Walsh G. Neoadjuvant treatment of postmenopausal breast cancer with anastrozole, tamoxifen, or both in combination: the Immediate Preoperative Anastrozole, Tamoxifen, or Combined with Tamoxifen (IMPACT) multicenter doubleblind randomized trial. J Clin Oncol. 2005; 23: 5108-16. doi: 10.1200/jco.2005.04.005.

41. Pfeiler G, Konigsberg R, Fesl C, Mlineritsch B, Stoeger H, Singer CF, Postlberger S, Steger GG, Seifert M, Dubsky $\mathrm{P}$, Taucher S, Samonigg H, Bjelic-Radisic V, et al. Impact of body mass index on the efficacy of endocrine therapy in premenopausal patients with breast cancer: an analysis of the prospective ABCSG-12 trial. J Clin Oncol. 2011; 29: 2653-9. doi: 10.1200/jco.2010.33.2585.

42. Sestak I, Distler W, Forbes J, Howell A, Cuzick J. Effect of body mass index on recurrence in hormone receptor positive early breast cancer - a retrospective exploratory analysis from the ATAC trial. Cancer Res. 2009; 69: 1047. 